НАУКОВИЙ ВІСНИК

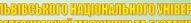

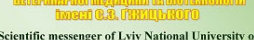

sientific messenger of Lviv National University
Veterinary Medicine and Biotechnologites

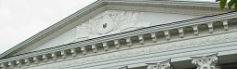

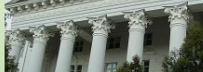

1

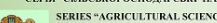

Tом 21 № 91

2019
Науковий вісник Дьвівського національного університету ветеринарної медицини та біотехнологій імені С.3. Гжицького. Серія: Сільськогосподарські науки

Scientific Messenger of Lviv National University of Veterinary Medicine and Biotechnologies. Series: Agricultural sciences

ISSN 2519-2698 print

https://nvlvet.com.ua/index.php/agriculture

doi: $10.32718 /$ nvlvet-a9116

UDC 619:615.241:636.3.084

\title{
The effectiveness of the use of drugs Globigen Pig Dozer and Globigen Jump Start when growing pigs
}

\author{
T.Y. Prudyus, Y.I. Kyryliv \\ Institute of Agriculture of Carpathian Region NAAS, Obroshyno, Ukraine
}

Article info

Received 16.09.2019

Received in revised form 14.10.2019

Accepted 15.10.2019

Institute of Agriculture of Carpathian region of Ukraine NAAS, Grushevskogo Str., 5, Obroshyno, 81115, Ukraine. Tel.: +38-068-185-63-48 E-mail:kyryliv@ukr.net
Prudyus, T.Y., \& Kyryliv, Y.I. (2019). The effectiveness of the use of drugs Globigen Pig Dozer and Globigen Jump Start when growing pigs. Scientific Messenger of Lviv National University of Veterinary Medicine and Biotechnologies. Series: Agricultural sciences, 21(91), 94-97. doi: $10.32718 /$ nvlvet-a9116

Currently, humanity owes great thanks to nature before the protection that nature has created is to protect the newborn. A person is born not sterile, but with protective appropriate antibodies transmitted from the mother. Antibodies, in the human body, have the ability to penetrate the placenta, and with blood flow, to be transmitted with maternal colostrum and milk. Unfortunately, not all living things have this advantage. Pigs are born sterile unless they are infected with viruses and toxins that have the ability to penetrate the placenta. In this case, they are sterile and defenseless, the whole environment is dangerous for them, and in this case there is no immunity and inevitable death. Therefore, after birth, the pigs themselves, or with the help of a sow that pushes them to the nipples with a snout, or an operator who receives farrowing, as soon as they try to drink precious colostrum, which loses its protective capacity every hour. The sow's colostrum contains not only nutritional, energy components, but also a more important component - Immunoglobulins. Immunoglobulins contained in colostrum provide piglets with passive immunity, but not all. Why? This is because the farrow is usually stretched or pathological. Pigs are born unevenly, so they eat colostrum differently. The last piglets, at birth, get the least amount of colostrum, or not enough at all. In addition, the quality of colostrum and the amount of immunoglobulins depend on the sow's age, the number of farrowing, whether the sows are vaccinated before farrowing, and the presence of viral pathogens and their vaccination. A good practice for pigs in the world, as well as in Ukraine, is the use of the Globigen Pig Dozer, which is given to the pigs orally to increase passive immunity and provide protection against viruses and bacteria.

Key words: immunoglobulins, egg, mortality, conservation, viruses, bacteria, passive immunity.

\section{Ефективність використання препаратів Глобіген Пиг Дозер і Глобіген Джамп Старт при вирощуванні поросят}

\author{
Т.Я. Прудиус, Я.І. Кирилів
}

Інститут сільського господарства Карпатського регіону НААНУ, с. Оброшино, Украӥна

На сьогодні людство велично повинно завдячувати природі перед захистом яке природа створила - ие захист новонародженого. Людина народжується не стерильною, а із захисними відповідним - антитілами захистом що передається від матері. Антитіла, в людському організмі, мають здатність проникати через плаченту, та із кровотоком, передаватися із материнським молозивом та молоком. Нажаль, не всі живі істоти мають таку перевагу. Поросята народжуються стерильними, окрім випадків, коли вони не заражені вірусами та токсинами, які мають здатність проникати через плаценту. В даному випадку вони $\epsilon$ стерильні, $і$ беззахисні, та усе навколишнє середовище небезпечне для них, і в даному випадку відсутній імунітет та неминуча смерть. Тому після народження поросята самі, або за допомогою свиноматки, яка рилом підитовхує їх до сосків, або оператора, який приймає опорос, чим швидше намагаються напитися дорогоиінного молозива, яке кожної години втрачає свою захисну здатність. Молозиво свиноматки містить в собі не тільки поживні, енергетичні складники, але і більш важливий компонент - імуноглобуліни. Імуноглобуліни, які містяться в молозиві, забезпечують поросят пасивним імунітетом, але не всіх. Чому? Це стається 
тому, що опорос, як правило є розтягнутим, або патологічним. Поросята народжуються нерівномірно, тож молозиво п'ють по різному. Останнім поросятам, при народженні, дістається молозива найменше, або зовсім не вистачає. Також якість молозива та кількість імуноглобулінів залежить від віку свиноматки, кількості опоросів, чи проводиться вакиинація свиноматок перед опоросом, та наявність вірусних збудників та їх вакцинопрофілактика. Непоганою практикою свиноводів світу, а також Украӥни, $\epsilon$ застосування препарату Глобіген Піг Дозер, який задають поросятам перорально для підвищення пасивного імунітету та надання захисту проти вірусів та бактерій.

Ключові слова: імуноглобуліни, яйще, смертність, збереження, віруси, бактерії, пасивний імунітет.

\section{Вступ}

У процесі становлення та розвитку імунології як науки, яка на початку входила в галузь мікробіології, найбільшої уваги приділялось пошуку та розробці препаратів, які посилюють синтез антитіл проти інфекційних збудників різного походження. В результаті цього пошуку були розроблені імуномодулятори, які використовувалися для розкриття механізмів імуногенезу. Найбільш ефективні 3 них використовувалися у практичній медицині.

Проте цей захист не завжди був ефективний, тому медична наука інтенсивно працювала над їх удосконаленням. Так, було створено ряд ад'ювантів, які значно посилювали продукцію антитіл (Mashkovs'kij, 1993; Leskov, 1999). Зокрема, було застосовано розроблено мінеральні сорбенти, зокрема гідроксид алюмінію, що використовувалися в якості ад'ютантів при проведенні масових вакцино-профілактичних заходів (Petrov \& Haitov, 1998).

Значний вклад у розвиток імуномодуляції внесли дослідження імунодепресивних властивостей численних препаратів, зокрема антиметаболітів пуринових агентів антибіотиків, стероїдів (Ljubimov \& Kovalenko, 2000; Haitov, 2000; Yeaman \& Yount, 2003), а також застосовування таких препаратів як імуран, мілеран, кортизол, циклофосфамід (Petrov et al., 1984). Ці розробки мали значний вплив на вирішення проблеми імуномодуляції. Зокрема, вони дали можливість перейти від визначення титрів антитілу у крові експериментальних тварин до кількісного визначення клітин, які виробляють ці антитіла, оцінювати дію препарату не лише на гуморальний імунітет, але і на клітинні фактори імунітету. Таким чином, з'явилася можливість кількісно оцінювати дію препарату на функціональну активність основних клітинних популяцій, які ініціюють імунну відповідь - Т- і Влімфоцитів, фагоцити в генетично контрольованих умовах досліду визначити дію імунодепресантів на основі функції стовбурових клітин - процеси їх міграції, проліферації та диференціації (Haitov, 2000). Це дозволило доказати, що більшість вивчених препаратів пригнічують реакції трансплантаційного імунітету, зокрема імуран, метотраксин, мілеран та інші. Вони є цитостатиками широкого профілю, що блокують ключові етапи біосинтезу нуклеїнових кислот i білків та пошкоджують більшість швидко проліферуючих тканин (кістковий мозок, лімфоїдну систему, епітелій кишківника та інше). Тому виникли особливі вимоги розробки доз і схем призначення імунодеприсантів та пошуку більш ефективних їх поєднань. Розробка нових підходів, до оцінки імуномодулюючої ефективності нових препаратів, позитивно вплинула на подальший розвиток клінічної імунології при по- шуку нових методів оцінки стану імунної системи людини і тварин в нормі та при захворюваннях, а також для призначення імуномодулюючих засобів $\mathrm{i}$ контролю проведеної терапії.

Поряд 3 препаратами і засобами імуносупревсивного типу, що застосовуються для пригнічення реакції трансплантаційного імунітету, лікування автоімунних захворювань, в арсеналі лікарських засобів важливо мати широкий спектр препаратів, які стимулюють реакції імунітету. В звязку із цим було розроблено принципово нові підходи до проблеми імуносупресії та імуностимуляції, які відкрили нові можливості до їх практичного застосування у різних галузях гуманної та ветеринарної медицини (Nikitenko, 1990; Molchanov et al., 2016; Khariv et al., 2017; Zhukova et al., 2017; Slivinska \& Lukashchuk, 2018).

Людський організм народжується із певним ступенем захисту. При формуванні людського ембріону антитіла мають здатність проникати через плаценту, а саме із кровотоком, а пізніше передаватися із материнським молозивом та молоком. Та нажаль, не всі живі істоти мають таку перевагу. Наприклад, поросята народжуються стерильними, крім випадків, коли вони заражені вірусами та токсинами, які мають здатність проникати через плаценту. В іншому випадку вони $€$ стерильні, і беззахисні, і усе навколишнє середовище небезпечне для них, оскільки у них відсутній імунітет та неминуча загибель. Тому, після народження поросята самі, або за допомогою свиноматки, яка рилом підштовхує їх до сосків, чи оператора, який приймає опорос, чим швидше намагаються напитися дорогоцінного молозива, що кожної години втрачає свою захисну здатність. Молозиво свиноматки містить в собі не тільки поживні, та енергетичні складники, але і більш важливий компонент - імуноглобуліни.

Імуноглобуліни, які містяться в молозиві, забезпечують поросят пасивним імунітетом, але не всіх. Чому? Це стається тому, що опорос, як правило є розтягнутим, або патологічним. Поросята народжуються нерівномірно, тож молозиво п’ють по різному. Останнім поросятам, при народженні, дістається молозива найменше, або зовсім не вистачає. Також якість молозива та кількість імуноглобулінів залежить від віку свиноматки, кількості опоросів, чи проводиться вакцинація свиноматок перед опоросом, та наявність вірусних збудників і їх вакцинопрофілактика.

Непоганою практикою свиноводів світу, а також України, є застосування препарату Глобіген Піг Дозер, який задають поросятам перорально для підвищення пасивного імунітету та надання захисту проти вірусів та бактерій.

Метою наших досліджень було вивчити вплив препарату Глобіген Піг Дозер на продуктивні показники новонароджених поросят. Даний препарат має 
неоднорідний склад: сукупність специфічних імуноглобулінів IgY (immunoglobulin yellow - імуноглобулін жовтий), соєва олія, вітаміни та пробіотик.

Основним носієм препарату є соєва олія, яке дає енергію поросятам для кращого руху, та є основним наповнювачем;

Вітаміни А, Д3, Е - відповідають за розвиток та скріплення слизової оболонки кишківника і $€$ антистресовим фактором для ворсинок кишківника;

Пробіотик - Enterococcus faecium NCIMB забезпечує оптимальні умови для розвитку позитивної мікрофлори.

Специфічні імуноглобуліни IgY захищають від:

- Clostridium perfringens

- Ротавіруус

- Трансмісивного гастроентериту

- E.coli Неонатальної diapeї та діареї при відлучu̧i(K88, K99, 987P)

- $S$. typhimurium

- Криптоспорідіозів.

\section{Матеріал і методи досліджень}

3 метою вивчення впливу препарату Глобіген Піг Дозер нами було сформовано дві групи свиноматок аналогів, порода велика біла, по 4 голови в групі. Дослід тривав 28 днів, починаючи із дня опоросу. Під час досліду враховували загальну кількість народжених та відлучених поросят, їх збереження, середню масу поросят при народженні та відлученні і середньодобові прирости.

Контрольна та дослідна група свиноматок отримувала стандартний раціон збалансований за поживними та біологічно активними речовинами. Дослідна група поросят отримувала, зразу після народження протягом трьох днів препарат Глобіген Піг Дозер в кількості 2 мл/голову/добу.

\section{Результати та їх обговорення}

В результаті проведених досліджень встановлено, що застосування специфічних імуноглобулінів зразу після народження, до перших порцій молозива призводить до підвищення збереженості поросят, збільшення приростів. Це можна побачити за результатами застосування Глобіген Піг Дозера в умовах свинокомплексу (таблиця).

\section{Таблиця}

Результати застосування Глобіген Піг Дозера в умовах свинокомплексу

\begin{tabular}{lcc}
\cline { 2 - 3 } & $\begin{array}{c}\text { Контро- } \\
\text { льна } \\
\text { група }\end{array}$ & $\begin{array}{c}\text { Глобіген } \\
\text { група }\end{array}$ \\
\hline Кількість свиноматок & 4 & 4 \\
Загальна кіл-ть народжених поросят & 46 & 42 \\
Загальна кіл-ть відлучених поросят & 41 & 41 \\
Смертність (\%) & $10,9 \%$ & $2,3 \%$ \\
Середня вага при нарождені (кг) & 1,33 & 1,25 \\
Середня вага поросят при & 7,56 & 7,75 \\
відлученні (кг) & 0,270 & 0,276 \\
Середньодобові прирости (кг) & \multicolumn{2}{|c}{} \\
\hline
\end{tabular}

Відомо, що у свиней лише невелика частина імуноглобулінів може проникати через плаценту або їх може синтезувати власна лімфоїдна тканина (Karput', 1981).

Застосування препарату Глобіген Піг Дозер за рахунок свого складу, зокрема, соєвої олії, яка є добрим джерелом енергії та пробіотика Enterococcus faecium NCIMB, що створює оптимальні умови для розвитку пасивної мікрофлори сприяє кращому всмоктуванні імуноглобулінів у новонароджених тварин і підвищує проникність слизової оболонки кишківника.

Застосування Глобіген Піг Дозера в умовах свинокомплексів у різних країнах світу показало позитивну тенденцію, зокрема, загибель поросят в маточнику знижувалася на 3\% та додатково було отримано 1 порося на свиноматку в рік.

Через 2-3 дні всмоктування імуноглобулінів у нормально розвинених поросятах припиняється. А як бути із поросятами в подальшому, після закінчення дачі Глобіген Піг Дозер? В подальшому ми продовжували підсилювати пасивний імунітет шляхом дачі сухих імуноглобулінів у складі предстартера поросятам, до часу поки повністю не сформується активний імунітет. Пасивний імунітет, набутий через молозиво, у поросят триває 5-7 днів, а активний ще не наступив, тому поросята стають знову беззахисні. Для цього було розроблена кормова добавка Глобіген Джамп Старт, в основі якої є специфічні імуноглобуліни IgY, які дають захист проти наступних збудників:

- Інфекційний гастроентерит

- Clostridium perfringens

- Ротавірус

- E.coli Неонатальна діарея (K88, К99, 987P)

- E.coli Діарея до та після відлучки (К88, К99, 987P)

- E.coli Набрякова - Коллібактеріоз (F18, К882)

- S. typhimurium

- Криптоспорідіоз

- Цирковірус.

Даний препарат можна задавати в предстартер та згодовувати тваринам вже з 4-5 дня життя. При цьому імуноглобуліни будуть постійно попадати в кишечник із кормом та систематично здійснювати захист кишечника, що є важливим сегментом у створенні імунітету.

Синтез власних антитіл починається лише 3 7-14денного віку поросят. Однак до 28 денного віку цей процес досить повільний. Слабка гуморальна відповідь на антигенну стимуляцію в цей період пов'язана 3 наявністю в організмі молодняка материнських антитіл, які блокують антигени що надходять та з недостатнім формуванням В-системи імунітету, що відповідає за синтез різних класів імуноглобулінів. Після приймання молозива кількість імуноглобулінів у сироватці крові поросят перевищує їх рівень у крові свиноматок. Повного розвитку імунна система у свиней досягає до 45-60 днів (Fesenko, 1980).

\section{Висновки}

Використовуючи кормові добавки Глобіген Піг Дозер та Глобіген Джамп Старт можна забезпечити пасив- 
ним імунітетом поросят від народження аж до 80-го дня життя, підвищити роботу шлунково-кишкового тракту, отримати додатково одне порося на свиноматку в рік та зменшити загибель на $3 \%$.

\section{References}

Fesenko, I.D. (1980). Nekotorye pokazateli vozrostnoj estestvennoj rezistentnosti organizma svinej. Bjul. Vsesojuz. In-ta jeksperim. Veterinarii, 38, 46-48 (in Russian).

Haitov, R.M. (2000). Pukovodstvo po jeksperimental'nomu (doklinicheskomu) izucheniju farmakologicheskih sredstv. M., 33-38 (in Russian).

Karput', M.V. (1981). Imunnaja reaktivnost' svinej. MN: Urozhaj, 52-86 (in Russian).

Khariv, I., Gutyj, B., Hunchak, V., Slobodyuk, N., Vynyarska, A., Sobolta, A., Todoriuk, V., Seniv, R. (2017). The influence of brovitatoxide in conjunction with milk thistle fruits on the immune system of turkeys for eimeriozic invasion. Scientific Messenger LNUVMBT named after S.Z. Gzhytskyj, 19(73), 163168. doi: $10.15421 /$ nvlvet7334.

Leskov, V.P. (1999). Immunomoduljatory. Allergija, astma, klinicheskaja imunologija, 4, 12-25 (in Russian).

Ljubimov, B.N., \& Kovalenko, T.P. (2000). Rukovodstvo po jeksperimental'nomu (doklinicheskomu) izucheniju novyh farmakologi-cheskih sredstv. M., 25-32 (in Russian).

Mashkovs'kij, M.D. (1993). Preparaty korrigirujushhie processy immuniteta (immunomoduljatory, immunoprotektory). Lekarstvennye sredstva. Posobie dlja vrachej. M., 192-209 (in Russian).

Maslianko, R.P., Padovskyi, A.L., \& Hryzhak, Ya.I. (2012). Imunomoduliatsiia reaktsii i imunitetu.
Suchasnyi stan rozvytku ta perspektyvy. Naukovyi Visnyk LNAVM, 14, 3(33), 174-181 (in Ukrainian).

Molchanov, A.A., Zhukova, I.O., \& Antipin, S.L. (2016). Substantiation of the use of phytobitics to correct protective functions of swine body. Scientific Messenger of LNU of Veterinary Medicine and Biotechnologies. Series: Agricultural Sciences, 18(1), 76-80. https://nvlvet.com.ua/index.php/agriculture/ article/view/3504 (in Ukrainian).

Nikitenko, A.M. (1990). Rol' immunomoduljatorov v korrekcii immunobiologicheskoj reaktivnosti i v profilaktike gemoblastozov zhivotnyh. Avtoreferat dis.d-ra vet. Nauk: Kazan' (in Russian).

Petrov, R.V., \& Haitov, R.M. (1998). Iskusstvennye antigeny i vakciny. M. (in Russian).

Petrov, R.V., Lopuhin, Ju.M., Cheredeev, A.N. (1984). Ocenka immunnogo statusa cheloveka. Metod rekomendacii. M. (in Russian).

Salyha, N., \& Vishchur, O. (2002). Formuvannia klitynnoho imunitetu porosiat pid vplyvom imunomoduliatora tymalinu. Visn. Lviv. un-tu, seriia biolohichna, 29, 165-170 (in Ukrainian).

Slivinska, L.G., \& Lukashchuk, B.O. (2018). Therapeutic effectiveness of probiotic and phytobiotic for gastroenteritis of weaned piglets. Scientific Messenger of Lviv National University of Veterinary Medicine and Biotechnologies. 20(87), 85-88. doi: 10.15421/nvlvet8717.

Yeaman, M.R., \& Yount, N.Y. (2003). Mechanisms of antibacterial peptide action and resistence. Pharmacol. Rev., 55, 27-55. doi: 10.1124/pr.55.1.2.

Zhukova, I.O., Molchanov, A.A., \& Antipin, S.L. (2017). Increase in resistance of pigs to oxidative stress by means of plant origin. Scientific Messenger LNUVMBT named after S.Z. Gzhytskyj, 19(74), 3337. doi: $10.15421 /$ nvlvet 7408 . 